\title{
The Two Faces of Urbanity: Exploring Global and Local Values-Two Urban Studios in Taksim Square and along the Shores of the Golden Horn in Istanbul
}

\author{
Kezban Ayça Alangoya \\ Istanbul Bilgi University, Faculty of Architecture, Department of Architecture
}

\begin{abstract}
Since the 18th century, the irritating but also fascinating scenes of urbanity - a complex phenomenon with cultural, social, political, economic, temporal, spatial, functional, and formal dimensions - have been described in literary works. Many seemingly opposite facts, such as individuality/society, freedom/loneliness/socialization, anonymity/strangeness/identity/belonging, diversity/chaos/segregation, indifferent city-dweller/initiative citizenship, have been revealed through literary works, travel and utopian writing, urban theories, scientific studies, manifestos, and newspaper articles. On the one hand, there are those who advocate a life outside the city because they consider the problems produced by the city and the phenomenon of density which they perceive merely in quantitative terms, as unsolvable problems. On the other hand, there are those who see the production of loose urban fabric as a solution or those who accept the (seemingly) opposite facts of urbanity as positive values and therefore support city life. All of these ideas are still as actual today as they were in the past. We are often unable to use our citizen rights to the city, to encounter different classes (social/ethnic/religious), to experience heterogeneity as an aspect inherent in city life and in the route of our daily life - following the orders of the capitalist system mainly organized around work - and we are often drawn into the same districts on the same paths. Our perception of our urban environments may get monotonous and shallow, but the irritating yet fascinating features of the first big cities still exist and may be grasped and brought into consciousness. Throughout their architectural education, especially in urban design studios, students can be encouraged to investigate the rhythm of their daily life, the conditions of their urban environments, and discovering the city as an intellectual and sensual programme, so that the phenomenon of urbanity can be grasped not just on formal, but on various other dimensions as well. This study focuses on the process and outcomes of two urban studios located in Taksim Square and along the shores of the Golden Horn in Istanbul. Taking the multidimensional content of urbanity into account, acquired theoretically through literary works and studies on urban planning and its history, the main aim of these studios has been the phenomenological understanding of the dynamic content of urbanity by the students. Through creative analysis of permanent/temporary spaces engendered by the diversity of user profiles and actions discovered on phenomenological excursions, students examine the qualitative values of density and global and local dynamics. We believe that designing spaces as "prototypes" helps highlight the multidimensional content of urbanity. The present study aims not only to highlight the multidimensional content of urbanity, but also to encourage its discussion in architectural design education and to emphasize the positive contribution of theoretical readings and phenomenological studies to urban design studios. The present study also aims to emphasize the beneficial correlation of global and local dynamics as the two faces of urbanity; important more than ever for the big cities of the 21 st century if we advocate for a vivid and resilient city life and citizens.
\end{abstract}

Key words: Urban design studios, creative analysis process, phenomenological excursions, global and local dynamics for urban resilience.

\section{Introduction}

Urban design studios in architectural education have

Corresponding author: Kezban Ayça Alangoya, associate professor, Dr., research fields: the city in the 20th century, developing educational methods for urban design studios, and phenomenological excursions in cityscapes. E-mail: alangoya@hotmail.com. gained particular importance in the context of examining the relationship between the physical environment and social life. In the training field, which has slower internal dynamics compared to the application field where needs have to be met quickly, it is possible to create an environment where everyday life can be observed in depth and awareness can be 
raised about the phenomenon of urbanity - a complex phenomenon with cultural, social, political, economic, temporal, spatial, functional, and formal dimensions. Students can be encouraged to investigate the rhythm of their daily life, the conditions of their urban environments, and discovering the city as an intellectual and sensual programme, so that the phenomenon of urbanity, which includes global and local values can be grasped not just on formal, but on various other dimensions as well. This study focuses on the process and outcomes of two urban design studios in Istanbul. Due to the rhythm of modern life which has gained so much momentum, students no longer have sufficient time to become aware of the multidimensional content of urbanity. The aim of the first phase of the design studios was therefore to acquire information from main concepts and facts of the modern city through literary works and studies on urban planning and its history. The aim of the second phase was the phenomenological experience of these concepts and facts about the global and local dynamics of urbanity. After many discussions in the studio, the students chose two sites in Istanbul; in Taksim Square and along the shores of the Golden Horn. Inspired by readings, students concentrated on some concepts of urbanity, which were in turn reflected on their projects names $[1,2]$.

\section{The Global and Local Values as the Two Faces of Urbanity}

\subsection{Exploring the Global Values of "Urbanity" from} Literary, Sociological, and Philosophical Works

18th 19th-century cities, which are the living spaces of the modern individual, have transcended being mere metaphorical tools in the works of literary authors, sociologists, and philosophers, and have become sources for phenomena and concepts related to urbanity. Indeed, the study of text types that constitute the heterogeneous structure of the literary world, such as literary works, travel and utopian writing, sociological and philosophical texts, and newspaper articles on the city and its citizens, contributes to the development of modern urban theory and how the phenomenon of urbanity is understood in architectural education, at least as much as works produced in the fields specific to architecture and the city. Derived from these text types, the impressions of the modern city can be ordered in the following categories: descriptions of social and physical conditions; designed cities in utopian-dystopian literature; structural conception of works woven with the conception of urban life; the modern individual; The others and their spaces; city routes and the day's flow. These impressions, which highlight the correlation between the capitalist system and everyday life, reflect the dramatic change of the social, cultural, and physical environments with clarity and offer useful concepts for understanding the phenomenon of urbanity. Accompanying the students of urban design studios during their phenomenological studies in urban fields, they contribute to awareness-building for stages and actors of modern life and to discoveries about the global values of urbanity $[3,4]$.

\subsection{Exploring the Local Values of "Urbanity" in Terms of the 20th-Century Pro-/Anti-city Debate}

The phenomena and concepts pertaining to the global values of urbanity are also inherent in the field of space creation-urban theories/scientific studies/texts on projects-buildings-settlements/ manifestos. Mostly focusing on the spatial, functional, and morphological contexts of urbanity, the works of planners, architects, and theorists bear witness to how they take pro- or anti-city positions, in the context of the city being the space of opportunities offered and problems created by modern life. The awareness for local values of urbanity came into the focus of urban theorists and planning by the mid-20th century through their criticism of the functional city's monotonous urban spaces. As per the subject of this paper, we may attempt to categorize the pro-city positions as follows: the anatomy of the city-dweller; critique of suburban life; urban form; critique of the functional city; and the 
local values of urbanity

(morphology-nature-history/sensory perception/social engagement of the citizen) [5].

\section{Beyond Polarization: Experiencing the Global and the Local as Values of Urbanity}

From the emergence of the first large cities to our day, thinkers, either within the specific field of architecture or outside it, have expressed phenomena such as individuality/groups/classes/society, freedom/loneliness/tolerance/socialization/integration/ segregation, anonymity/strangeness/identity/belonging, diversity/contrasts/ chaos, indifferent city-dweller/ initiative citizenship, modern/historical/natural, discontinuity/continuity, zoning/mixing, mental/ sensory. Rather than polarization, these phenomena reflect the rich content of urbanity and urban field as the space of encounters. As is the case with these phenomena, which arise from experiencing life in modern cities, the statements of thinkers in favor of city life describe the characteristics of the global and the local, which constitute the two inseparable faces of urbanity. The main protagonists of global life in the modern city are distanced, free, and intellectual city-dwellers who constitute a new social type coexisting with others. Their socially and aesthetically transformed living environment is shaken by anonymity, heterogeneity, density, and events that challenge individual perception and communication. The protagonists of local life in the modern city claim mixed-use urban spaces as a public domain that they share with other city-dwellers, where they communicate, feel a sense of belonging, express democratic rights, and, if necessary, unite to defend their city and neighborhood. They also advocate protection of local values of built (historical buildings and urban tissues) and natural environments. The relationships of global and local values, which nourish one another and are at the basis of the rich content of the phenomenon of urbanity, gain importance within the context of the resilience of cities and their citizens.
However, it is still of particular importance to emphasize the fact that the relationship between values of any kind can only offer chances and possibilities in democracies $[6,7]$.

\section{The Global Face of Urbanity in Taksim Square}

\subsection{The Studio Process}

Spatial dynamics peculiar to global cities become especially visible in squares where public life is concentrated. Historically, culturally, and politically, Taksim Square has a special place in the memory of Istanbulites and has a multi-layered spatial organization that takes time to grasp (Figs. 1-3). ${ }^{1}$

\footnotetext{
${ }^{1}$ The square takes its name from its primary element, the still-existing water cistern called maksem which was built in 1730 to distribute water to surrounding districts. The second element of the square was the Taksim Military Barracks (1780), one of barracks of an unusual scale emphasizing the importance of the army and built in the place of imperial gardens, small palaces, and houses which were all demolished. The third element was the area which embraces the Republic Monument and was redeveloped as the Republic Square in 1928. The function of the Taksim Barracks was later altered with the addition of wooden stands in its courtyard which was used as a stadium (1922). The barracks were altogether demolished (1940) during the Republican era as part of French urban planner Henry Prost's green valley project which extended between districts and covered this entire urban area. The first part of this green valley overlooking the square (the $38,000 \mathrm{~m}^{2}$ area where the artillery barracks stood) was called Gezi Park, becoming the Republic's first park and the second element of the square to be converted. A large pool with a fountain (1990 1991) was built in the centre of the rectangular park and closed spaces were built on the park's periphery (1967), making use of the difference in elevation. Although national and international contests were held for Taksim and other major squares in the city (1984 1989), due to the priority given to motor traffic and the challenges of high rent in the metropolitan area, no concrete results were achieved and the square has ended up as a traffic square. The fourth element of the square was the Atatürk Cultural Center (AKM), one of the symbolic buildings of the Republic, opened in 1969 as the fourth largest cultural centre in the world at the time. In 2013, demolition of the centre (which had been closed for renovation purposes since 2008) and reconstruction of the barracks were under consideration by the government which began demolition work on Gezi Park. Although demolition of the park and uprooting of trees were halted by protests, they did tear down closed spaces. Traffic on the square was rerouted underground (2014) and the square was transformed into a barren void consisting of a monolithic expanse of concrete. The design proposals mentioned in this study respond to the situation preceding the Gezi Park protests [8].
} 


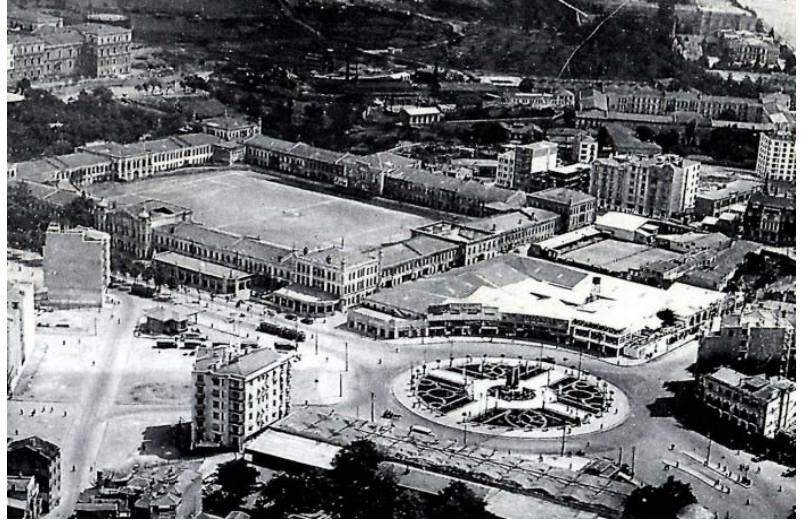

Fig. 1 Taksim military barracks.

Source: the author.

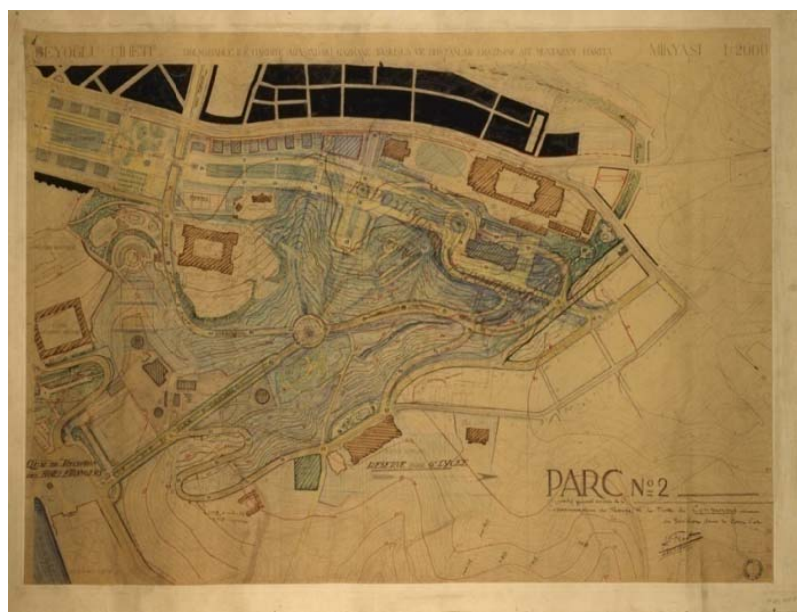

Fig. 2 H. Proust Plan.

Source: www.farklibirbakis.com.

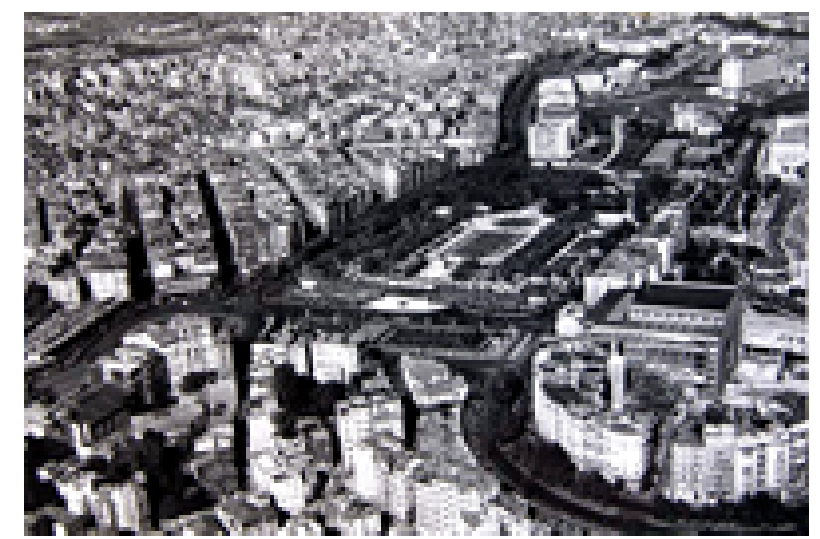

Fig. 3 Taksim Gezi Park, Taksim Square and surroundings.

Source: www.hayalleme.com.

Alternating between cognitive and phenomenological research makes it easier to understand the global phenomena inherent in the spatial organization of the square. Readings of cognitive maps at different scales and collaborative studio models allow us to mentally grasp the change of fabric of certain areas, the boundaries and quantitative relationships between the square and the surrounding areas, and the natural and built characteristics of its physical surroundings, while phenomenological excursions provide perceptual experiences that differ from the knowledge gained in the studio. The exuberant chaos of the global city can only be experienced inside it. On the square, the students developed awareness about the permanent/temporary, visible/hidden, quantitative/qualitative characteristics of physical reality and "the wide range of user profiles" while experiencing the dynamic life of the square. Concepts such as "inside-outside, dominance, unknown entrance, transition, metamorphosis and transformation, and boundary" which reflect the dynamism of the global city through the way spatially integrated sub-areas come into contact with one another became factual.

\subsection{Phenomenological Excursions: The Dynamism of the Global}

Students experienced that the square, which was described in the studio as "a flat expanse" and "an empty space where to spend a brief amount of time", contains "a surprising diversity of actions". They noticed that these actions (transportation/ waiting/meeting/crowding/dispersing/gathering/hiding /standing/passing/wandering/fixed-itinerant vending/ resting) create spaces whose boundaries are in motion and that they vary in terms of time of use (night/day/weekdays-weekends/after a concert-gamework) and of "visible/hidden physical phenomena" whose properties vary (sound-silence/smell/ heat-cold-wind/size-emptiness-fullness-density-crowd edness/speed). The experience of "the silence of the natural space" and that of the "ground that becomes slippery under the crowds" in the empty space of the square right next to the park could only have clashed on-site. In places such as "Balık Pazarı (Fish Market) 
and Istiklal Avenue," where temporary spaces were formed from sounds and smells, students experienced "the exuberance of the senses". During map readings in the studio environment, certain areas were not included in the design area and the collaborative studio model, because they were distant and had different fabrics and were therefore interpreted as having no connection with the square. During phenomenological excursions, the students noticed that Taksim Square has a spatial effect that "transcends that empty space that first comes to mind and interacts with its surroundings". Taking into consideration the spatial integrity and continuities they had discovered, they redefined the boundaries of the design area. On account of the fact that they contained "vital continuities that nourish the square, thus stretching its impact", some areas were included in the design area as "sub-areas". They took out areas that "form closed spaces in terms of action and structural characteristics" and "are detached from the design area" even though they are close to the square.

By making it possible to simultaneously observe spaces of permanent/temporary actions, this 1:500 model serves as a "model-photo," rendering visible the global values peculiar to large cities (Figs. 4 and 5).

\subsection{Final Products: Prototype Solutions}

The discovery of the extensive content of the phenomenon of urbanity was concluded with the development of open-ended suggestions whose main principles have been formulated, rather than formally rigid project proposals. The "Design Thinking" idea that design is not an object but an action, becomes concrete through the urban groundscape that brings together diverse user profiles while taking into consideration the actions and needs of city-dwellers.

\subsubsection{Form in the Global City}

In this 1:500 studio model (Fig. 6 and 7), one notices the road network which gives the impression of "a surface set atop" the soil ground of the park. The designer (Asl1 Elmac1), who perceived the ground of the avenue and square as "shell-like hard surfaces," focuses on how "the soft ground of the earth is covered with the city's hard shell". She stretches the phenomenon of "urban shell" towards the park and the

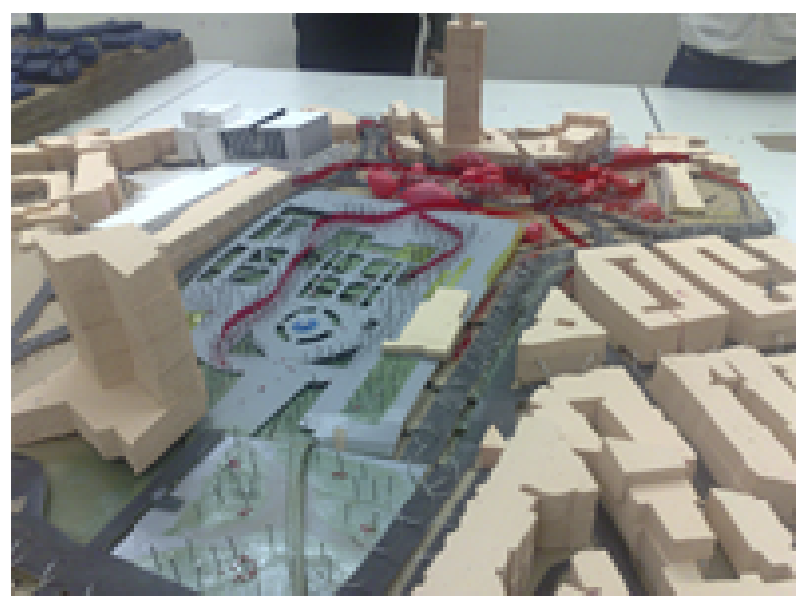

Fig. 4 Urban shell.

Source: the author.

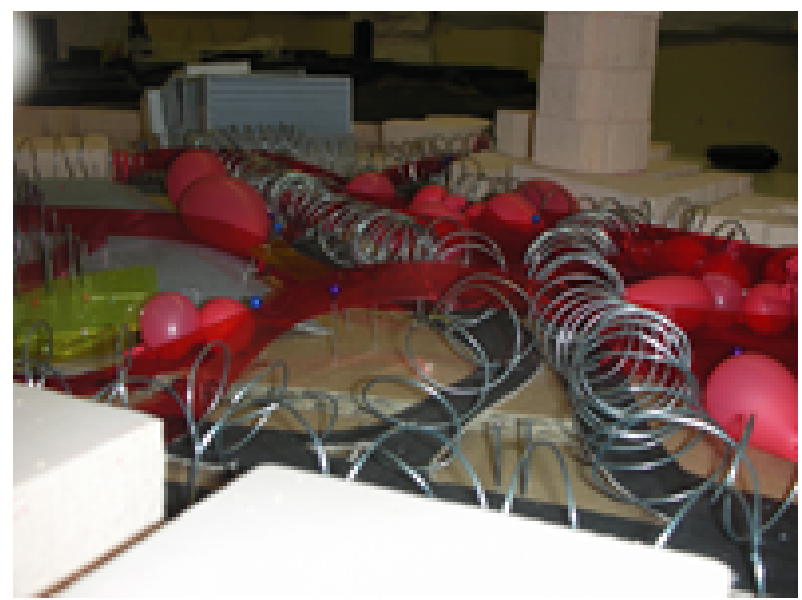

Fig. 5 The 1:500 model as a "model-photo".

Source: the author.

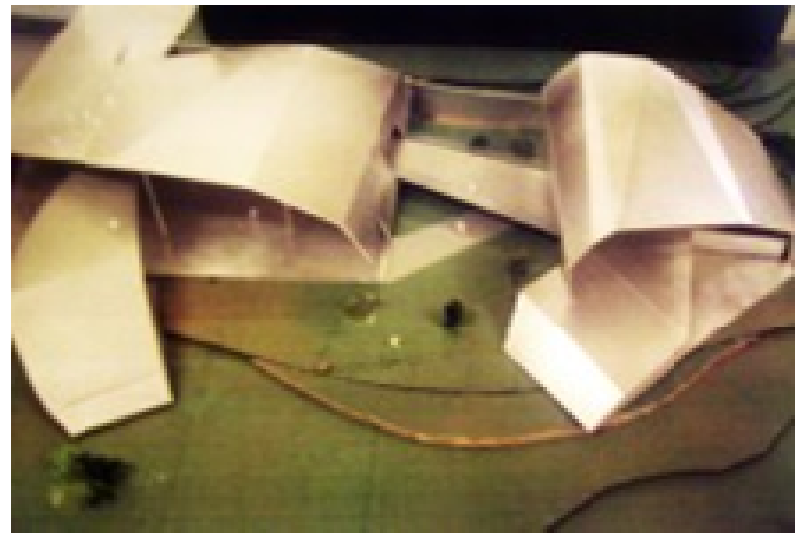

Fig. 6 Urban shell.

Source: the author. 

Taksim Square and along the Shores of the Golden Horn in Istanbul

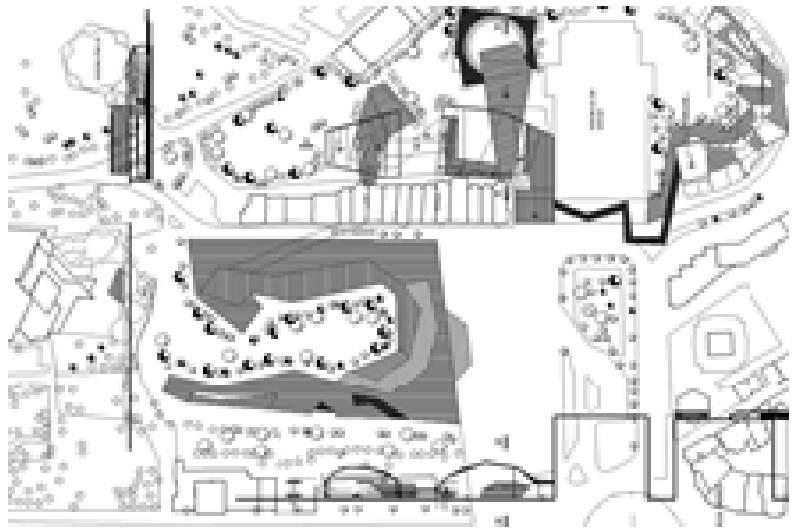

Fig. 7 Urban shell.

Source: the author.
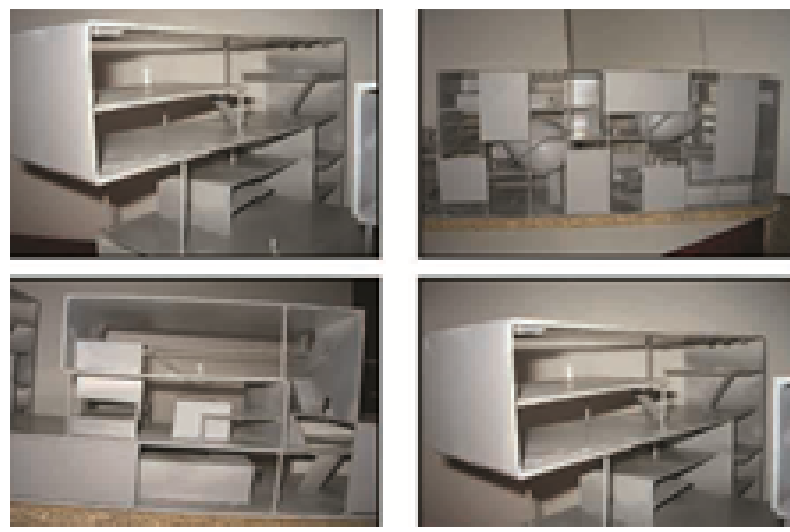

Fig. 8 The anonym face of the global.

Source: the author.

space of the square, aiming to render visible the soft ground of the earth. The urban shell itself bends into different shapes to form spaces for artistic events and activities.

In Fig. 8, the designer (Kivanç Balli) opens to "heterogeneous dwellers of a big city" the diversity of actions and spaces (studios/halls/terraces) which has been kept closed to the public behind the "silent, plain, prismatic mask" of the AKM building, a legacy of modern Turkish architecture. He thus designs a building containing "open/semi-open/closed" spaces that are accessible from outside but connected to the AKM building for "new open-ended cultural/social/technical programs".

\subsubsection{Metropolitan Contradiction}

In Fig. 9, the park acquires an "indoor space" isolated from the dynamics of the square through clearly-defined boundaries, the play of levels, varying user profiles, and temporary spaces for action that are built and dismantled according to the differing day and night life. The city-dweller "goes up into the park leaving the world behind" and "comes back down from the park to mingle into the crowd". The designer (Ela Bingöl) conceives these experiences pertaining to the global city between quietness and busyness and through doors, stretched grounds, and tunnels. She diversifies the programme of the AKM building with new cultural/social/technical programs.

In Fig. 10, the designer (Gizem Cabbar) renders transparent the rear façade of the AKM building not overlooking the square, and thus "opens it to the public". She also achieves this by "interconnecting the inner courtyards of offices via passageways" right next

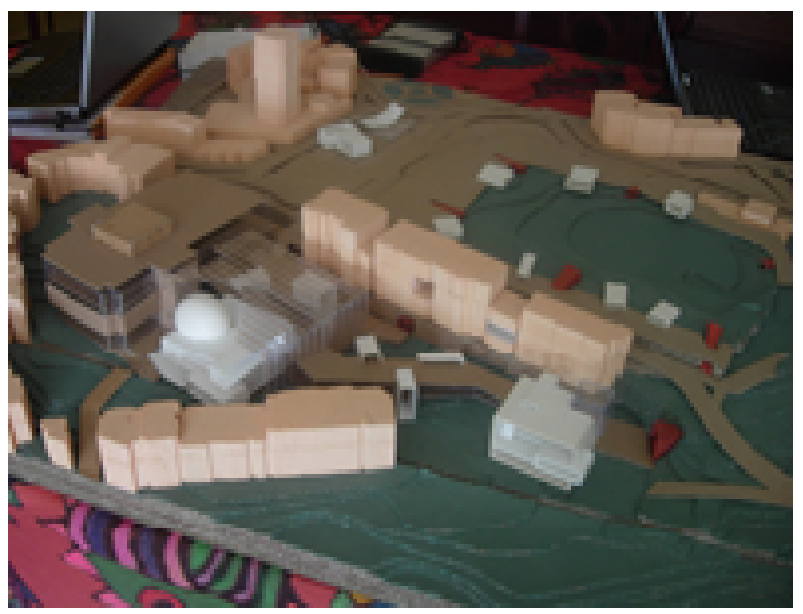

Fig. 9 Calmness and dynamism.

Source: the author.

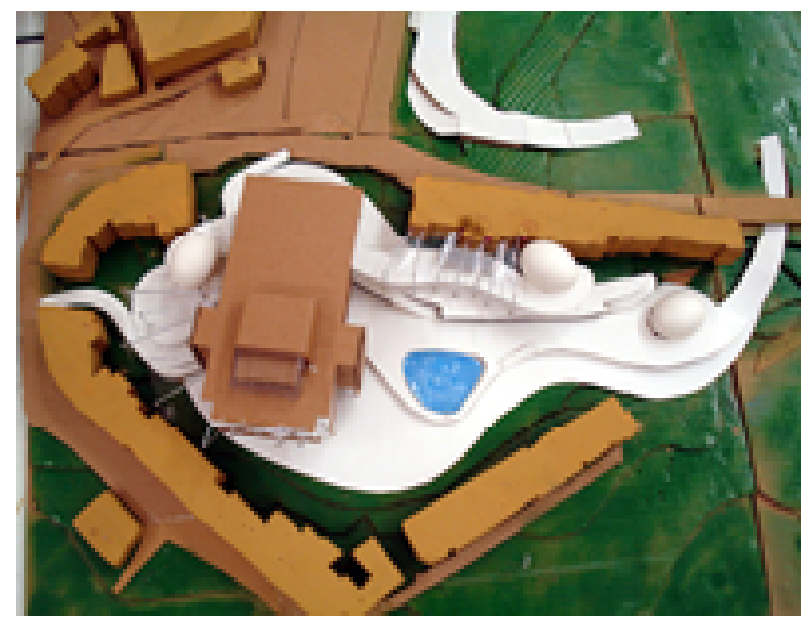

Fig. 10 Anonymity and belonging.

Source: the author. 
to the city square, which has anonymity and dynamism. She forms a new pedestrian route that is not clearly perceived from the square and proposes a public indoor space which gives a sense of belonging and where social platforms for recitals, talks and the like will be established in courtyards that will include bookshops, galleries, studios, and cafés.

\subsubsection{An Environment of Flows and Continuities}

In Fig. 11, the designer (Fulya Özkubat) connects "the hidden grounds of the metro which are deprived of natural light" to the main ground of the square and the lower grounds of the AKM building, and, by stretching them all along the square, brings them out into the daylight. The public use value of the AKM building is increased through additional buildings and through programmes whose grounds are linked to and diversified through the grounds of the sub-areas of the square. The AKM building thus transcends being the prismatic mass that is delimited by four surfaces and becomes "a passageway on the urban scale and a gate connecting districts to one another", while the square opens out to nature, the green valley, and the view of the Bosphorus.

In Figs. 12-14, due to the steep slope of the topography, the valley interrupts the continuity of the ground level of this green space, which faces the city and has three sides that are rather sharply delimited. In order to render visible its dimension and location between nature and city, the area is conceived so as to fit into a "spatial jigsaw". Besides the city park, flower gardens, green spaces, water surfaces, and walking/jogging/cycling trails, the design, which makes

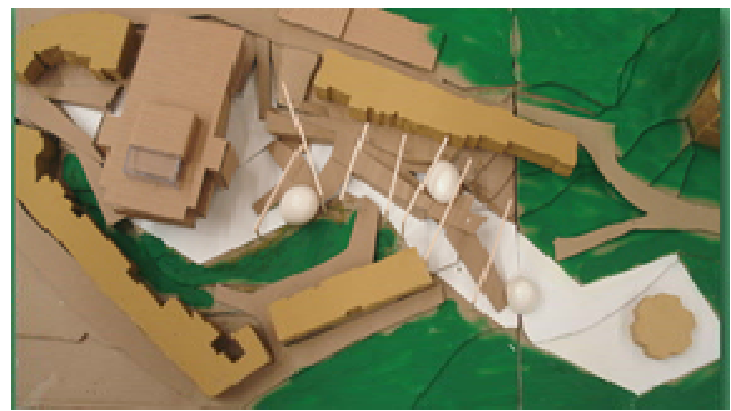

Fig. 11 The lightness of being in the flow of the crowd. Source: the author.

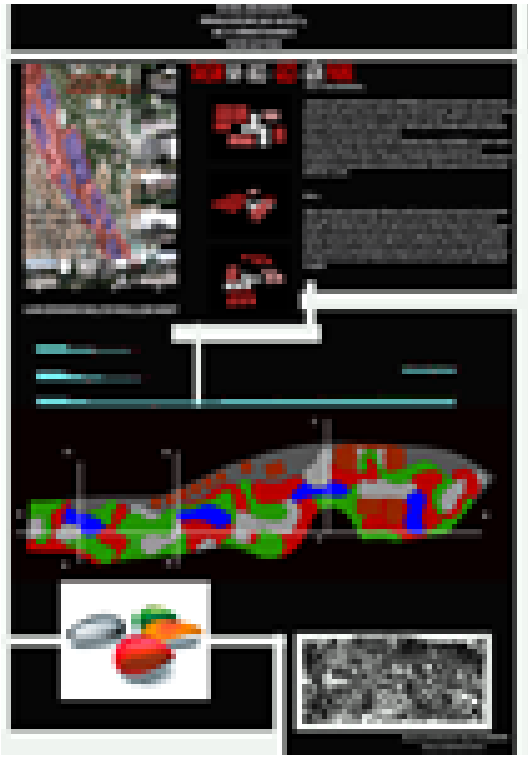

Fig. 12 Between two fabrics/two scales/two energies. Source: the author.

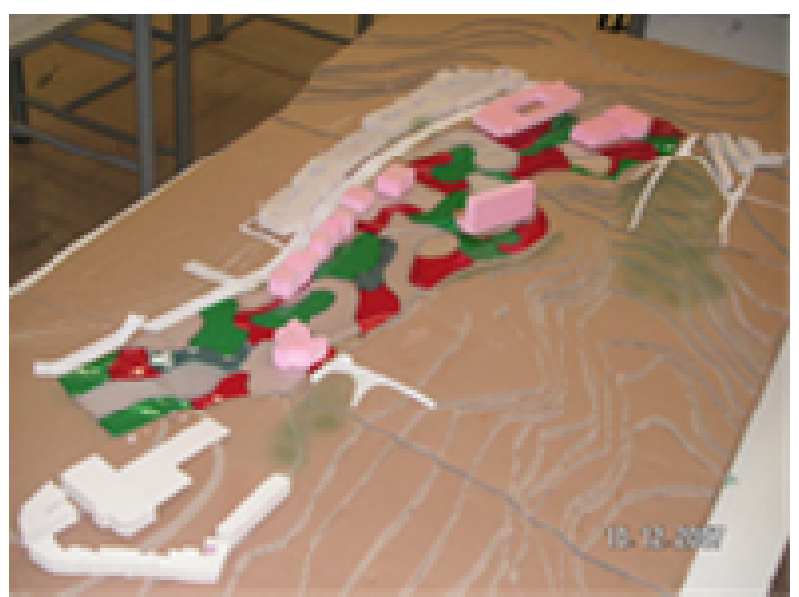

Fig. 13 Between two fabrics/two scales/two energies. Source: the author.

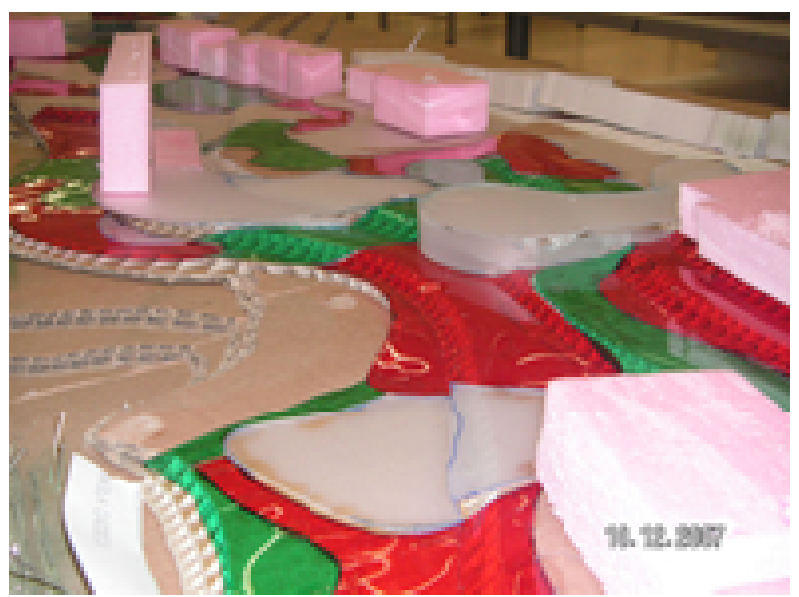

Fig. 14 Between two fabrics/two scales/two energies. Source: the author. 


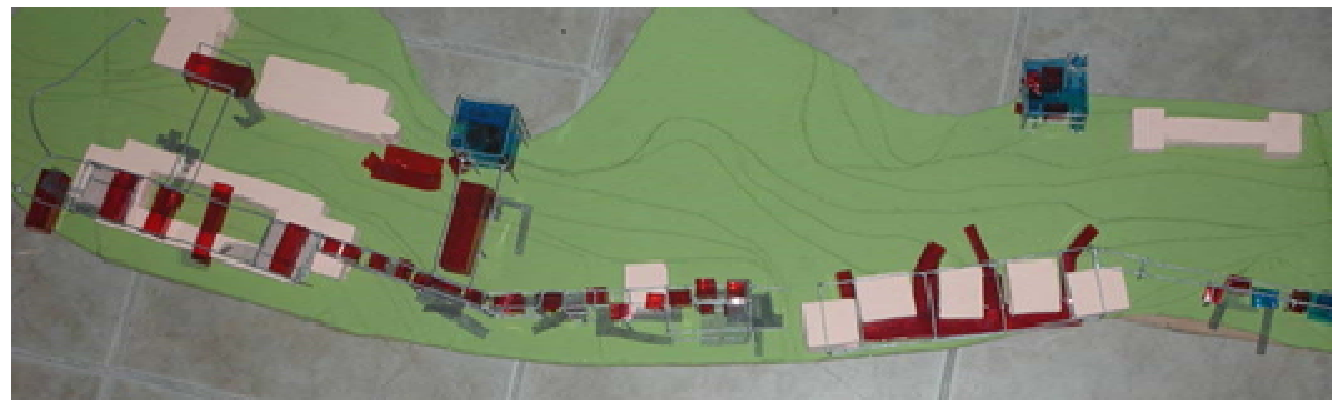

Fig. 15 Open city gates: home for us "others".

Source: the author.

use of the differences in level, offers indoor and outdoor spaces for cultural, sports, and recreation events and activities. The designer (Türkcan Uçar) has opened the metro station onto the park, wanting to attract visitors as well as the heterogeneous population of the area (university students/employees/residents of different age groups from neighboring districts/passers-by). Drawing inspiration from city life and natural environments, the designer proposes open-ended actions (student hall/short-term accommodation, sports/ festivals/performances/concerts/botanical gardens). He also proposes that existing institutions support its spatial integrity (opening closed gardens to the public, institutions diversifying their programmes so as to increase social interaction).

In Fig. 15, the designer (Eda Kinağ) interprets the spaces between office buildings, which form a boundary line between the avenue and the park, as "open city gates" and equips them with social service programmes such as dormitories, studios offering training courses in diverse fields, and indoor-outdoor sports areas for "people of all ages who are in need/people who have no one to care for them/asylum seekers/solitary mothers/students".

\subsection{The Current Condition of the Square}

In Fig. 17, with traffic being rerouted underground, the square lost its potentials and was deprived of vitality, virtually turning into the lifeless city centers of the functional city that began to be criticized with the 8th meeting of CIAM (International Congress of Modern Architecture) [5].

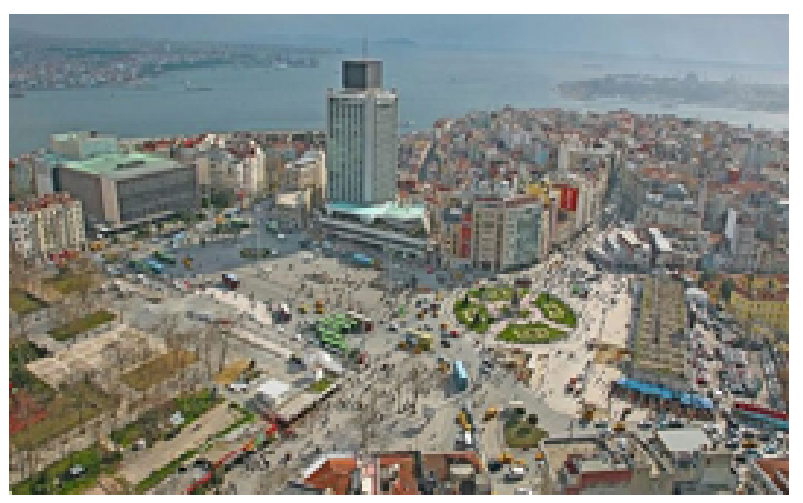

Fig. 16 Taksim Square in 2014.

Source: http://1insaat.biz/2014/01/10/taksim-meydani-cevre-du zenleme-ihalesi-16-ocakta/ and https://www.google.com.tr/sear ch?q=taksim + meydan $\% \mathrm{C} 4 \% \mathrm{~B} 1 \& \mathrm{biw}=1366 \& \mathrm{bih}=673 \& \mathrm{tbm}=$ is ch\&tbo $=$ u\&source $=$ univ\&sa $=X \&$ sqi $=2 \& v e d=0$ ahUKEwisgpm $5 \mathrm{kc} \_$LAhUiDJoKHcS6DscQsAQIGQ\&dpr=1\#imgrc=yKbK1e u5M $\overline{\mathrm{M}} 3 \mathrm{ZdM} \% 3 \mathrm{~A}$.

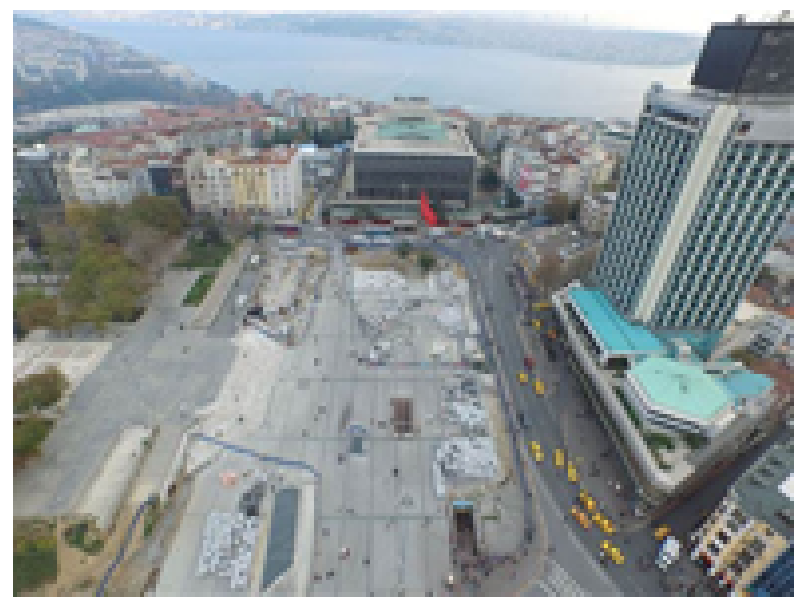

Fig. 17 Before and after: the visage of Taksim Square changed completely as of 2014.

Source: http://www.karar.com/gundem-haberleri/taksim-meyda nindaki-cevre-duzenlemesinde-sona-gelindi-54393. 


\section{The Local Face of Urbanity in the Golden Horn Area}

\subsection{The Studio Process}

The Golden Horn area has a coastal avenue that extends all along the shoreline, between the neighborhoods on the stone hills built up with dense housing blocks (Figs. 15-17) and the shore below. The avenue is laden with semi-public institutions such as hotels, universities, and convention and business centers, which are lined up in front of the housing fabric situated on the slope and turn their back on the neighborhood community, in terms of their programme, orientation, and scale. Phenomenological excursions were made to three neighboring districts in the area (Sütlüce, Halıcıoğlu, and Hasköy), with the intention of examining this situation, which unhinges the relationship between neighborhoods and the shore (see Section 4.3.2), and of discovering local values. In conjunction with excursions to these districts, which contain various historic buildings that are religious or secular and may or may not be registered, in the studio, students continued to do readings of cognitive maps and to construct models of the area at different scales and were expected to decide on their design area and develop programme proposals (Figs. 18-20).

Students gave priority to meeting the daily needs of the local population (shops, pharmacy, tailor, café, etc.). Also aiming to involve the neighborhood community

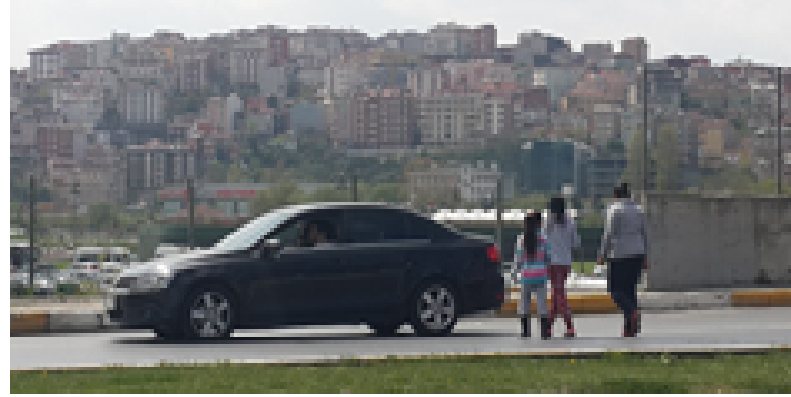

Fig. 18 Cityscape Golden Horn.

Source: the author.

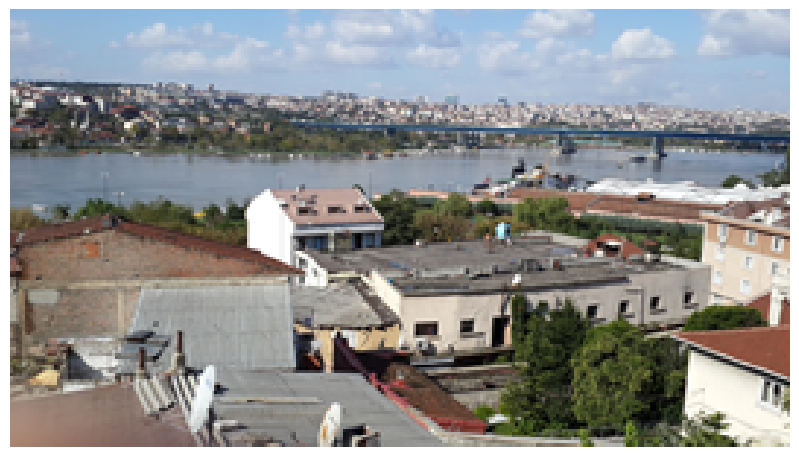

Fig. 19 Cityscape Golden Horn.

Source: the author.

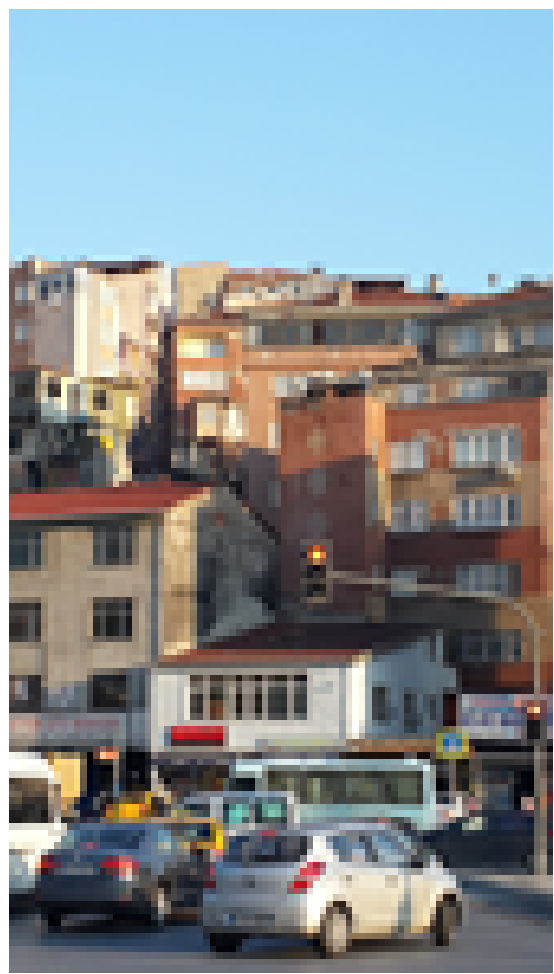

Fig. 20 Cityscape of stone hills at Golden Horn.

Source: the author.

in sharing the local values of their area with others (city-dwellers/tourists/students/residents of neighboring districts etc.), the students proposed urban programmes (city museums/hostels/student halls/education units/conference halls/libraries/arts and crafts workshops/shops/cafes/exhibition and performance spaces/sports areas, etc.) that would contribute to livening up the rhythm of everyday life and social life in the area. The final products, which render visible the local values of the area, were grouped under four categories (Figs. 21 and 22). 

Taksim Square and along the Shores of the Golden Horn in Istanbul

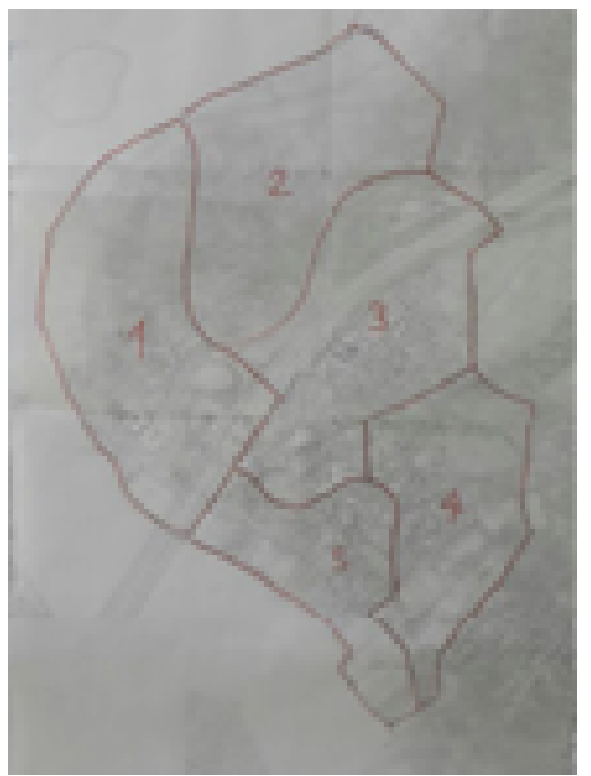

Fig. 21 Map of Hasköy.

Source: the author.

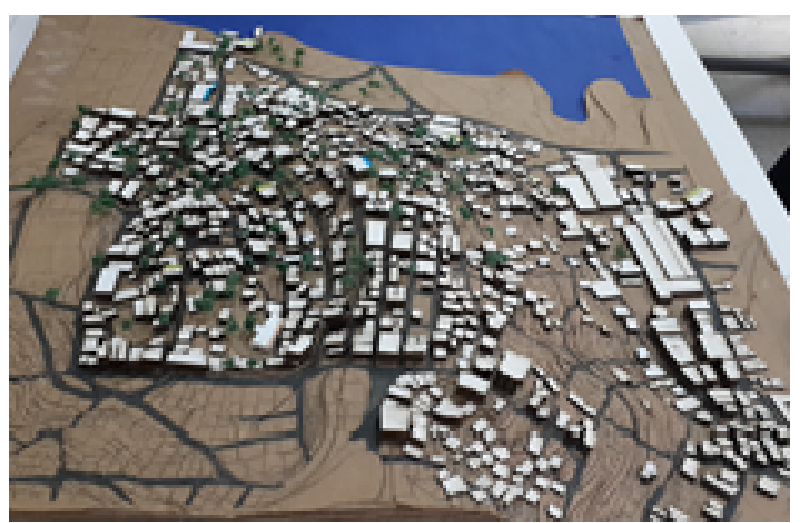

Fig. 22 Model of Hasköy.

Source: the author.

\subsection{Final Products: Prototype Solutions}

\subsubsection{Natural Values}

In Figs. 23-25, certain districts in the Golden Horn area, which extend from the shore to the hills, are both connected to the main avenue along the shore at the lower levels and, as a result of the dynamic topography of Istanbul, to the main avenues at the upper levels. The designers (Orhan Yıldırım and Betül Bolca) wished to recover the slope, which descends from the upper levels of the Sütlüce district to the shore (with a difference in elevation of $21 \mathrm{~m}$ ), as a natural space having public content. They propose a new square by

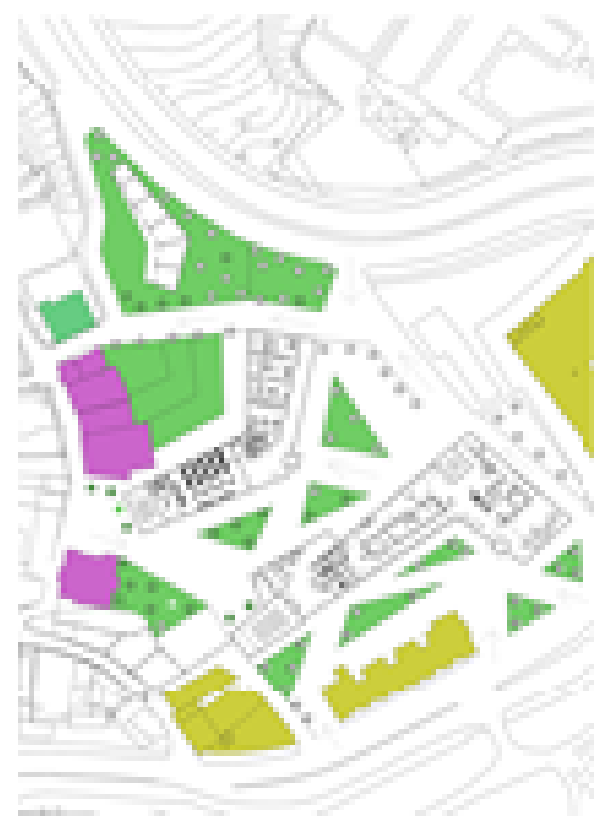

Fig. 23 Map of Sütlüce.

Source: the author.

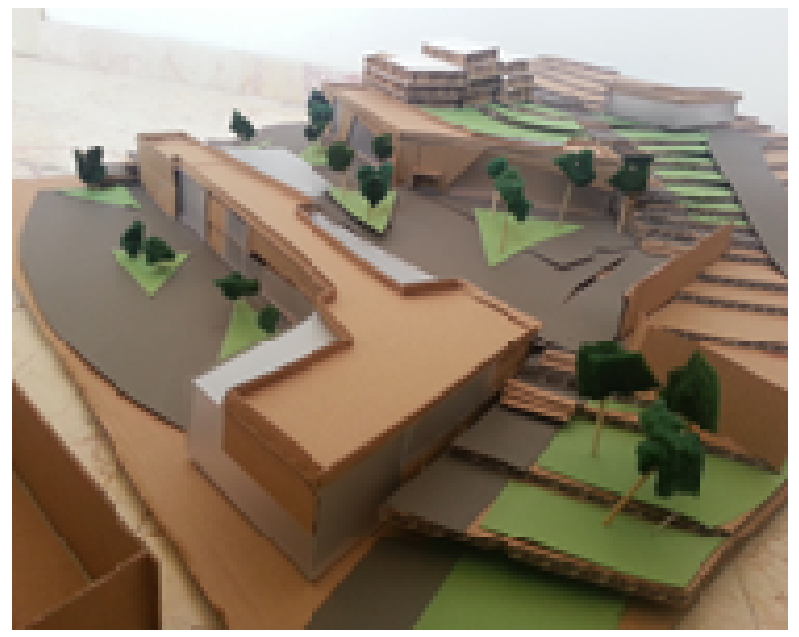

Fig. 24 A natural void in the district's fabric, Sütlüce. Source: the author.

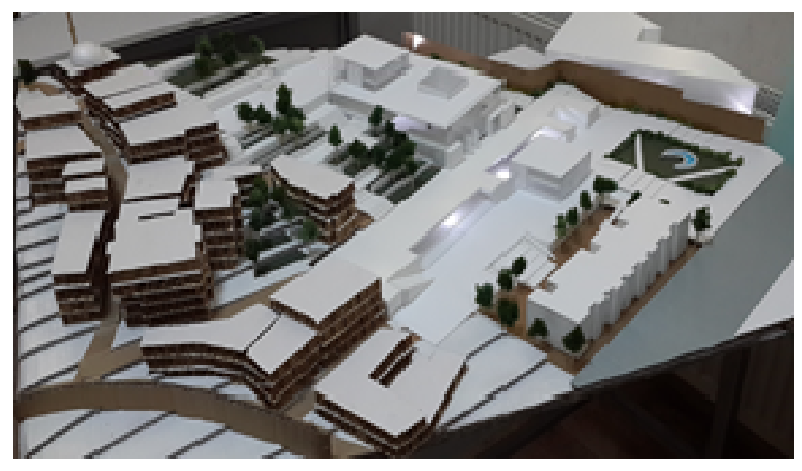

Fig. 25 Fluid topography and vital continuity.

Source: the author. 

Taksim Square and along the Shores of the Golden Horn in Istanbul

expanding the Mosque level situated at the upper entrance to Sütlüce towards the Golden Horn, they merge the slope with the streets of the district on the horizontal plane, and furnish the vertical space with mixed-used programmes.

In the Hasköy district, the historic synagogues and neighborhood streets, laid in a grid system by Jewish residents, merge with the organic settlement fabric of the Ottoman era. The designers (Cemile Şahin and Beyzanur Başaran) position their project in an area of rural character where the grid fabric of the streets at the upper levels of the district ends and the slope reaches shore level. Making use of the slope and adding garden terraces, they redesign the large mass of the existing elementary school building, which is incongruent with the district's fabric. In addition to this, they propose mixed-used public programmes for district residents as well as a sports area and a park where city meets nature (Figs. 26 and 27).

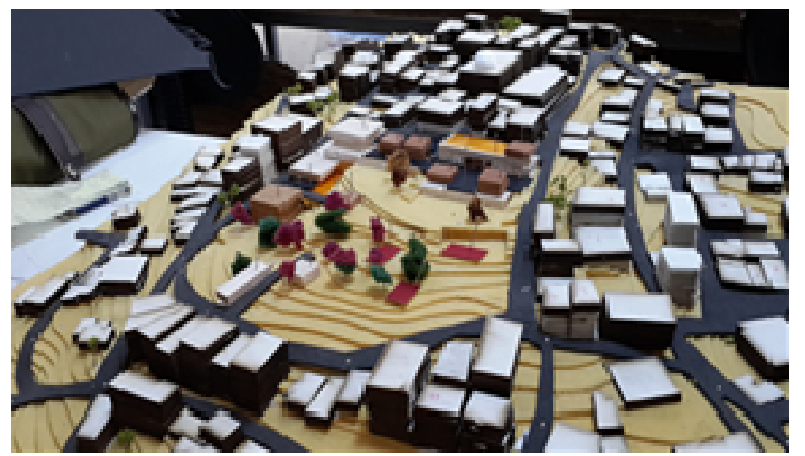

Fig. 26 A natural void in the district's fabric, Hasköy. Source: the author.

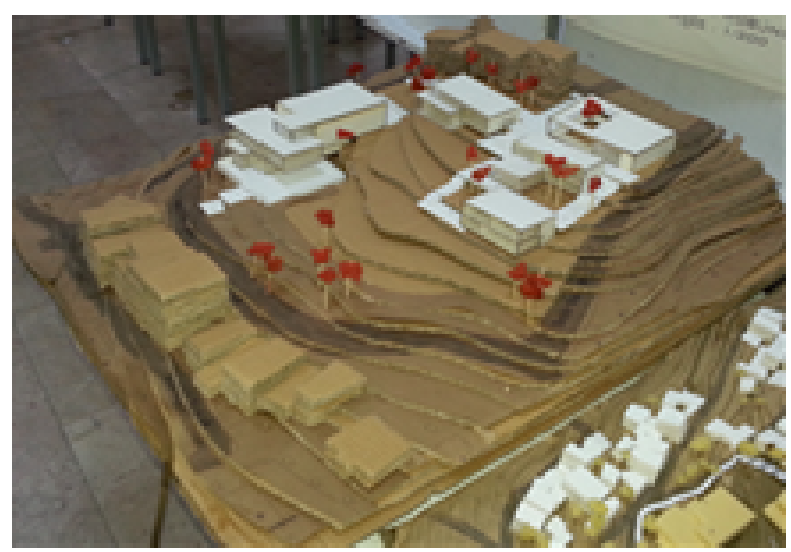

Fig. 27 A natural void in the district's fabric. Source: the author.
In Figs. 28-30, it is possible to discover rich topographic movements in Hasköy's inner fabric. Having noticed that the ground surface is shaped in the form of two juxtaposed dishes, the designer(Seyyide Göksal) integrates two buildings and the Home for the Aged built by the Jews in the same area with her designs of an urban park. Proposing mixed-used programmes she diversifies the area's user profile and social life.

5.2.2 Strategic Elevations: Overcoming Vital and Structural Disconnections

Şaban Deresi Avenue provides access from the main avenue along the shore to inner parts of the Halıcioğlu

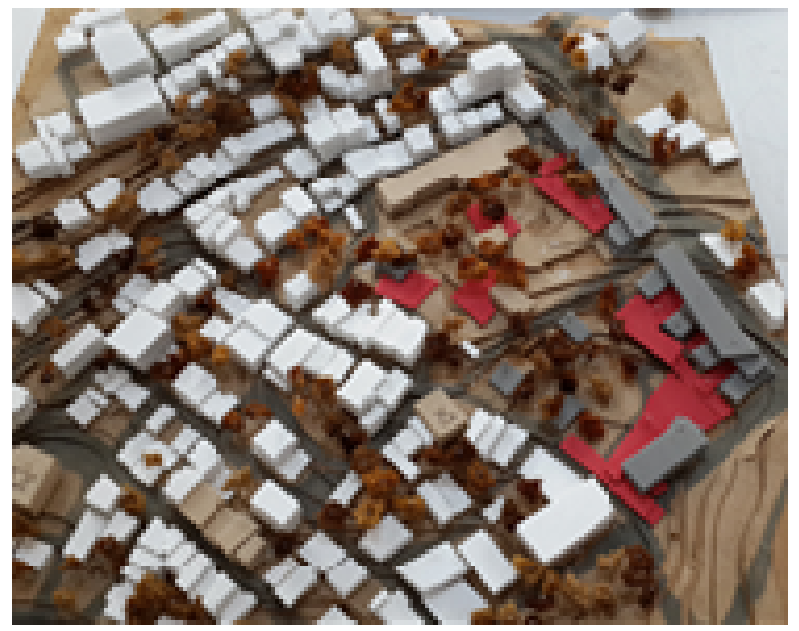

Fig. 28 Topographic dynamics peculiar to the area, Hasköy.

Source: the author.

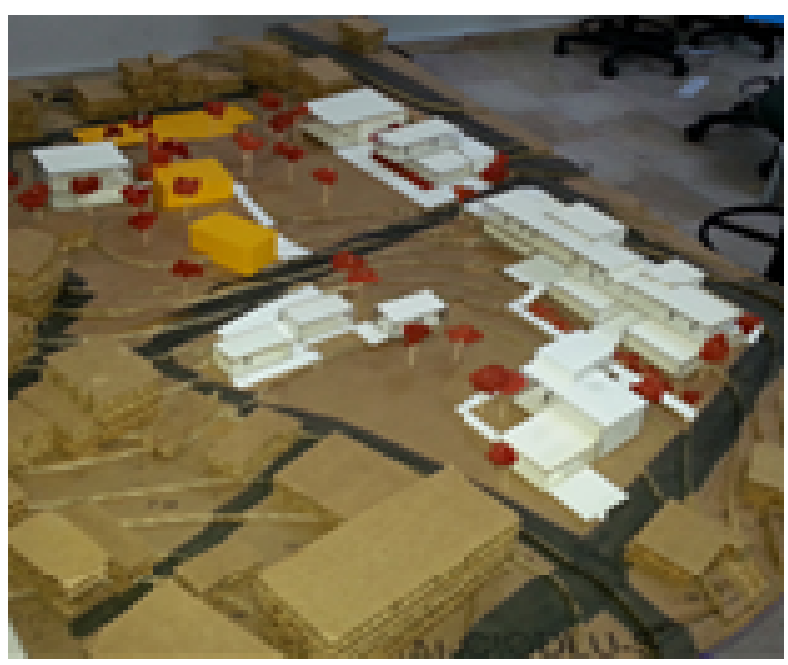

Fig. 29 Topographic dynamics peculiar to the area, Hasköy.

Source: the author. 


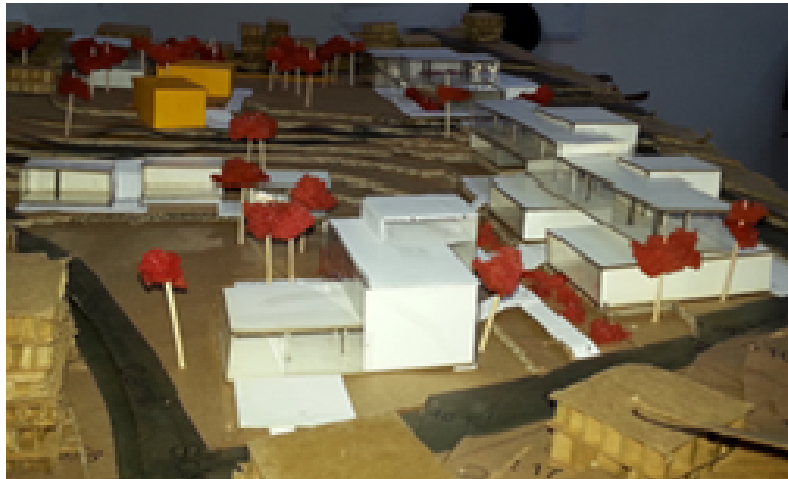

Fig. 30 Topographic dynamics peculiar to the area. Source: the author.

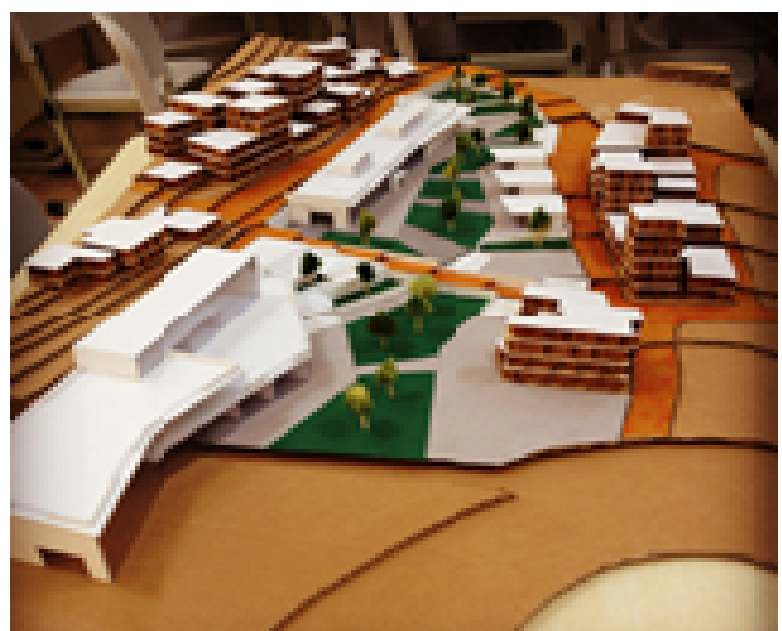

Fig. 31 Neighborhood residents and city-dwellers meet, Halıcıoğlu.

Source: the author.

district and neighboring districts. Despite being a major access route, the avenue does not offer public spaces that would enliven everyday life for district residents. Having discovered the vital disconnection between the avenue and the neighborhood where residences are located, and the difference in elevation of $5 \mathrm{~m}$, the designer (Ömer Ünlüsoy) enriches this difference with spaces where the neighborhood community, district residents, and city-dwellers can meet and socialize. Besides cultural and commercial programmes that are linked to both the avenue and neighborhood levels, the neighborhood level is enlivened by cafes and shops that serve the daily needs of the local population (Figs. 31-33).

The main avenue has parks and sports areas on the sea front and residences on the slope side. On the latter

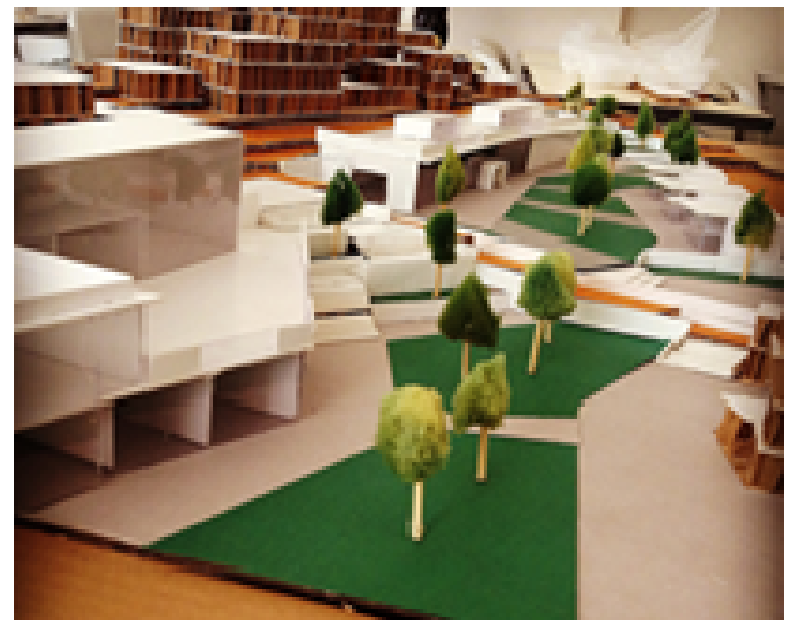

Fig. 32 Neighborhood residents and city-dwellers meet, Halıcıoğlu.

Source: the author.

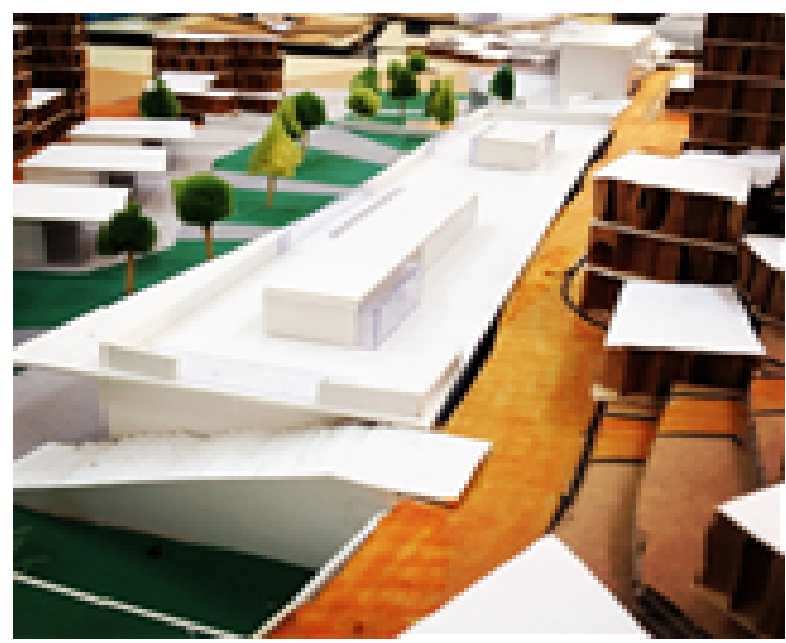

Fig. 33 Neighborhood residents and city-dwellers meet, Halıcıoğlu.

Source: the author

level, the designer (Elif Yalçınkaya) proposes a city museum and arts and crafts workshops, while on the neighborhood level, she proposes a library building and a terrace opening onto the view, with shops where neighborhood residents can spend time. Aiming to facilitate the access of the neighborhood community to the park on the shoreline, she carries hard and soft surfaces all the way up to the avenue level (Figs. 34 and 35).

On one end of Hasköy Avenue, which extends along the shoreline, is a historic bath with a difference in elevation of $4 \mathrm{~m}$ between the avenue and the neighborhood street where the church is located. The 


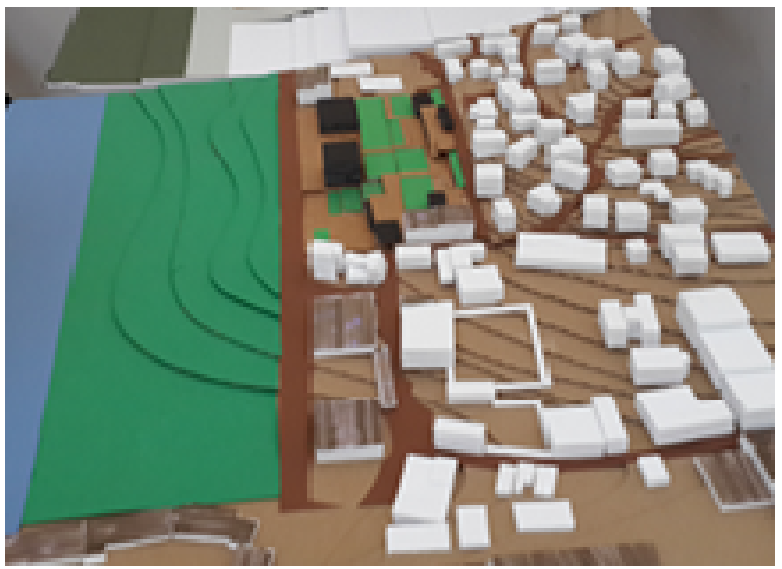

Fig. 34 Neighborhood residents and city-dwellers meet, Hasköy.

Source: the author.

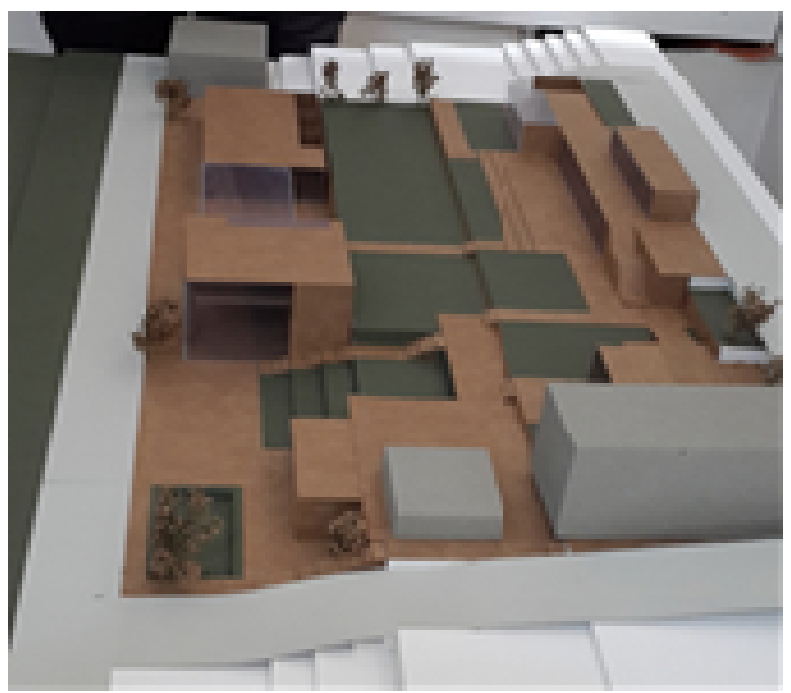

Fig. 35 Neighbourhood residents and city-dwellers meet, Hasköy.

Source: the author.

designers (Zeynep Akdere and Kübra Konat) turn the roads between city blocks into pedestrian walkways and enrich the differences in elevation with new public grounds (such as the new commercial square below the avenue level). Proposing mixed-used programmes for use by neighborhood residents and city-dwellers, they carry the green fabric of the shore onto the design area (Figs. 36 and 37).

5.2.3 Strategic Areas: New Centers that Penetrate into the Fabric

The districts, which from a distance are perceived as a mass of residential units, contain inspiring structural and vital fabrics in inner areas. The residents of the introverted neighborhood of Çıksalın in the Halıcıoğlu district prefer to use the small number of service units (bus stops/shopping and health centers/marriage bureau) on the upper levels rather than those on the shore. Having observed that there is a lack of social interaction among neighborhood residents, the designer (Ayşenur Özkara) proposes a public square (children's play areas/local market/arts and crafts workshops/exhibition units/performance spaces/district library/cafés etc.) that can be used by residents of all ages. Terracing the square by taking into account the levels on which the streets flow into the area, she designs a viewing platform looking out on the panorama of the Golden Horn (Figs. 38 and 39).

In Figs. 40 and 41, there are industrial units large and small, all along Okmeydanı Avenue, which provides access into the inner parts of the Hasköy district. The designer does not want to destroy the identity of the industrial area, whose buildings have not

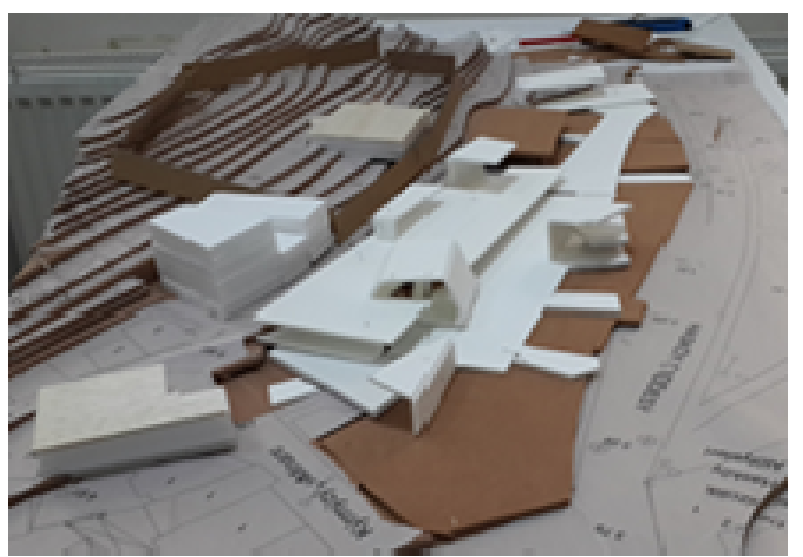

Fig. 36 Neighborhood residents and city-dwellers meet, Hasköy.

Source: the author.

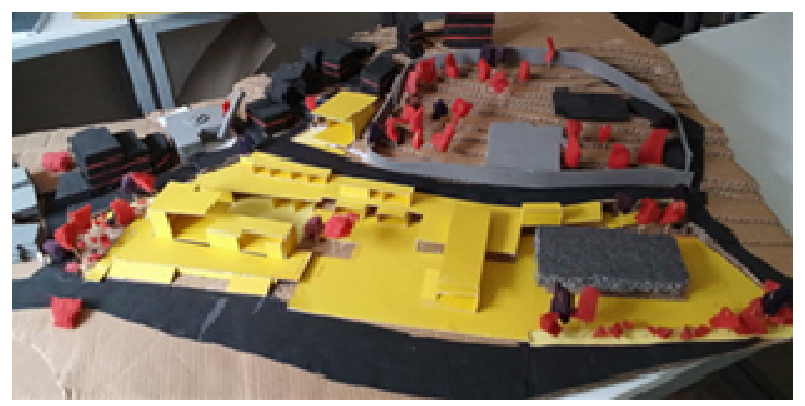

Fig. 37 Neighborhood residents and city-dwellers meet, Hasköy.

Source: the author. 


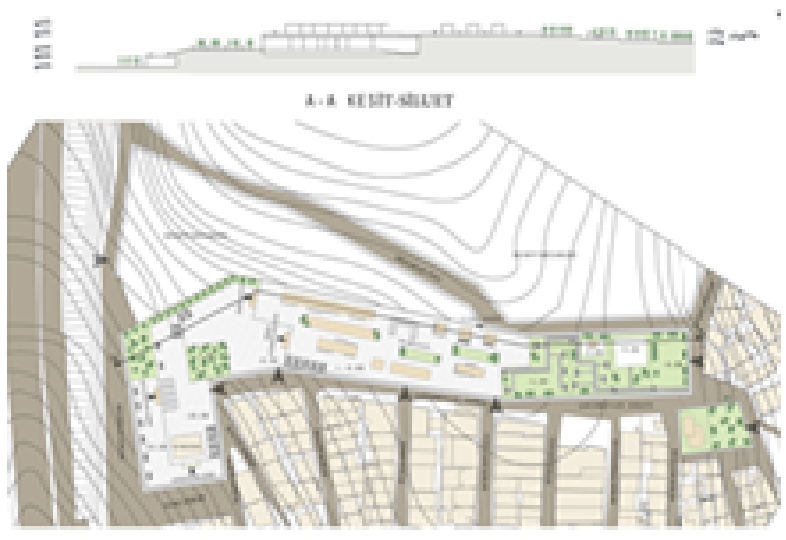

Fig. 38 Living on hilltops, Sütlüce.

Source: the author.

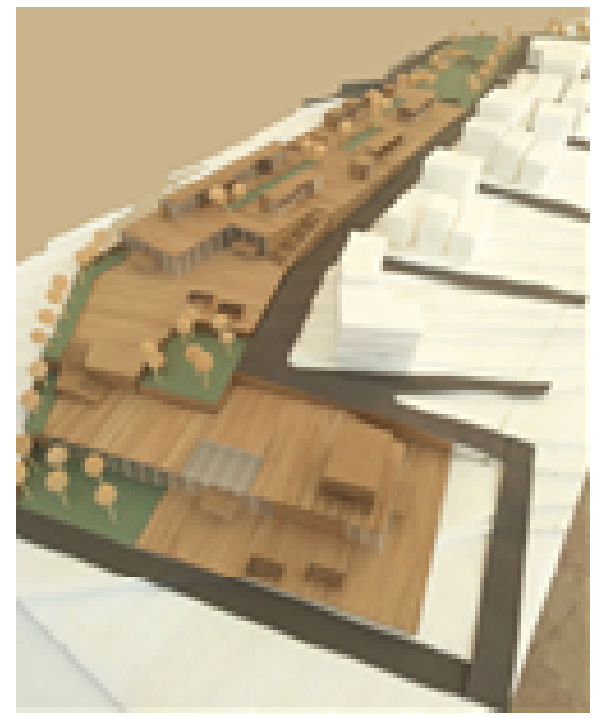

Fig. 39 Living on hilltops.

Source: the author.

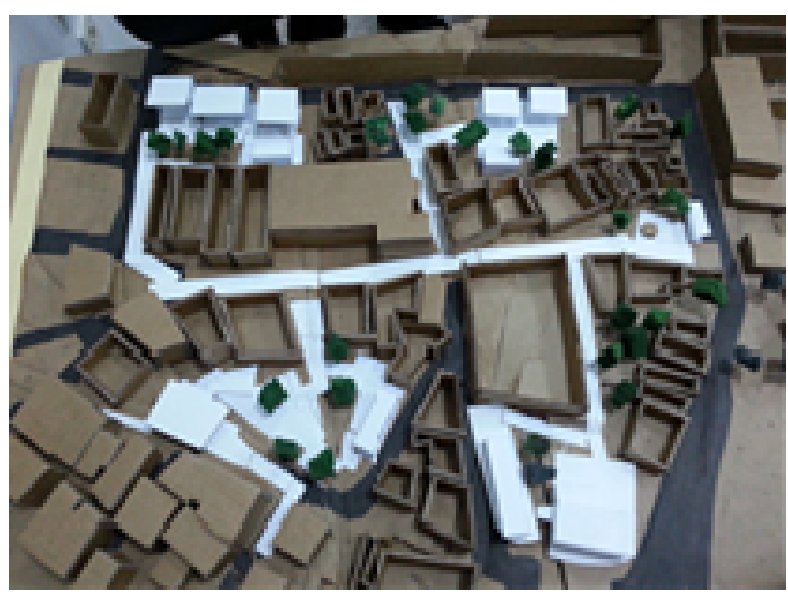

Fig. 40 Tribute to the historic industrial fabric, Hasköy. Source: the author.

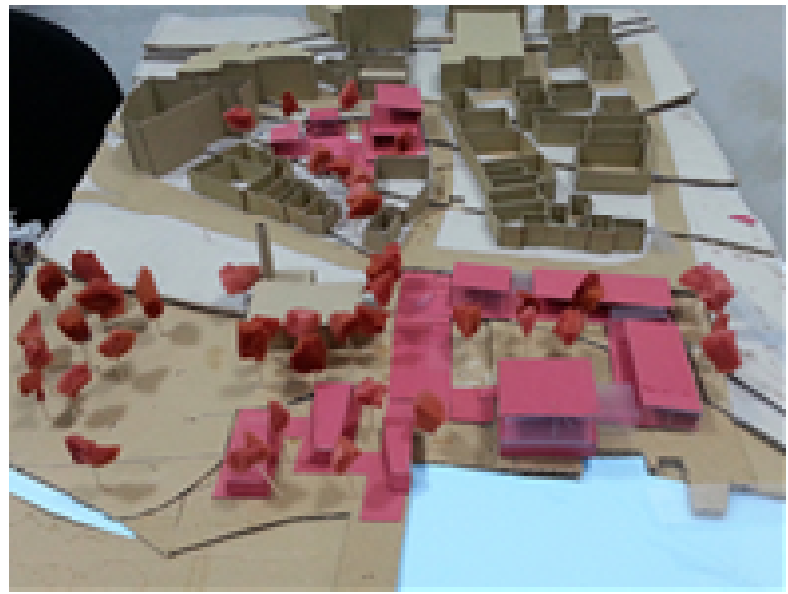

Fig. 41 Tribute to the historic industrial fabric.

Source: the author.

been registered but date far back. Perceiving the avenue as a spine and using the bystreets that penetrate into the industrial fabric, the designer (Şadıman Sezer) proposes industrial workshops in courtyards, and a library and shops around the middle and high school building. Merging the avenue and neighborhood levels on the slope by a market square, on the shore the designer (Sümeyye Erbaş) proposes shops and arts and crafts workshops for the district's women.

5.2.4 The Local Values of a History of Global Value The designer (Zahide Nur Baykam) proposes a route that provides access from the shoreline level up to the higher levels, that activates historic sites (churches/synagogues/historic walls etc.) hidden within the inner fabric of the Hasköy district, and brings together both visitors and district residents with the built and natural assets of the district (topography/view etc.). Three stops are envisaged on the conceived route: A city museum is proposed at the first stop close to the shore; arts and crafts workshops, exhibition units, viewing terraces, and shops at the second stop; and shops and a district library that is linked to the district elementary school at the third stop (Figs. 42-44).

Having discovered an area in the inner parts of the Hasköy district full of historic sites and opening onto the view of the Golden Horn, the designer (Sümeyye 
The Two Faces of Urbanity: Exploring Global and Local Values-Two Urban Studios in Taksim Square and along the Shores of the Golden Horn in Istanbul

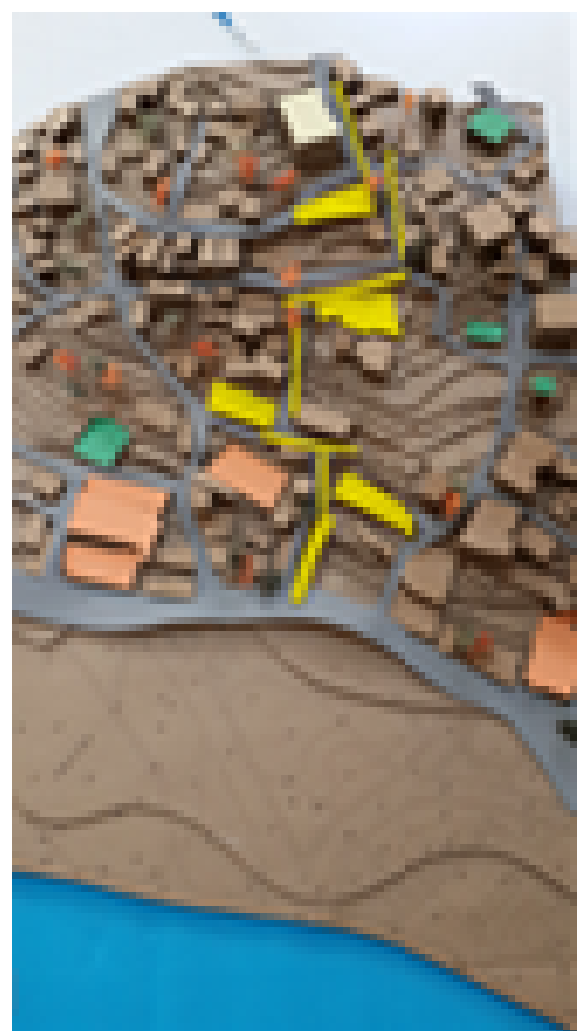

Fig. 42 Creating a route that penetrates inward, Hasköy. Source: the author.

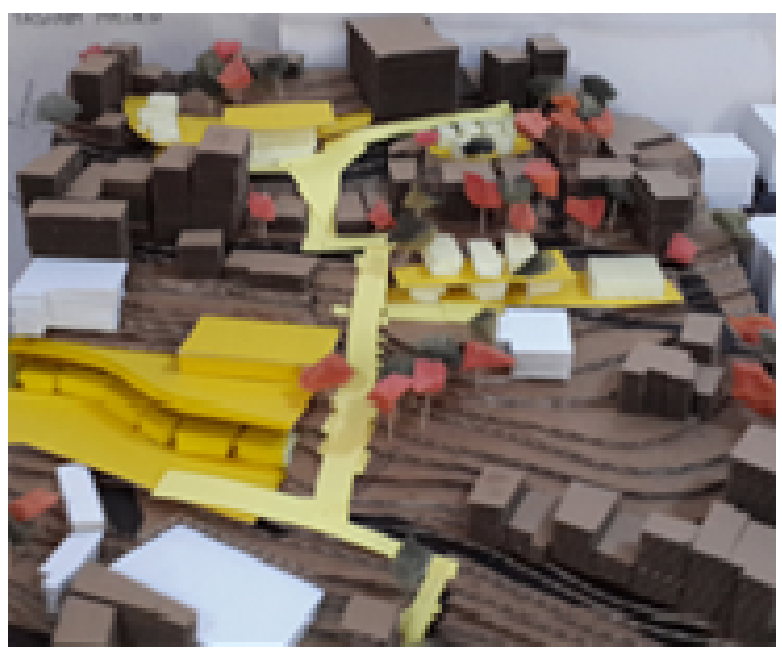

Fig. 43 Creating a route that penetrates inward, Hasköy. Source: the author.

Dursun) interprets the area as an open-air museum for visitors and district residents. Taking into account the existing street fabric and levels, she proposes a city museum, arts and crafts workshops, and a library building, and designs series of shops where district residents can meet their daily needs (Figs. 45 and 46).

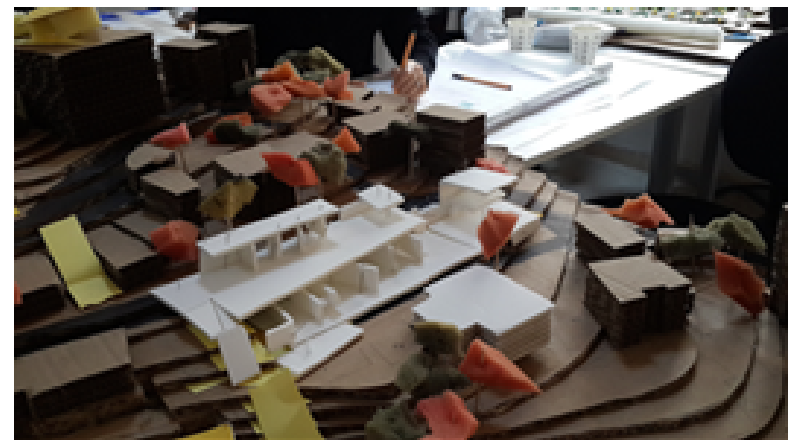

Fig. 44 Creating a route og global value that penetrates inward of locality.

Source: the author.

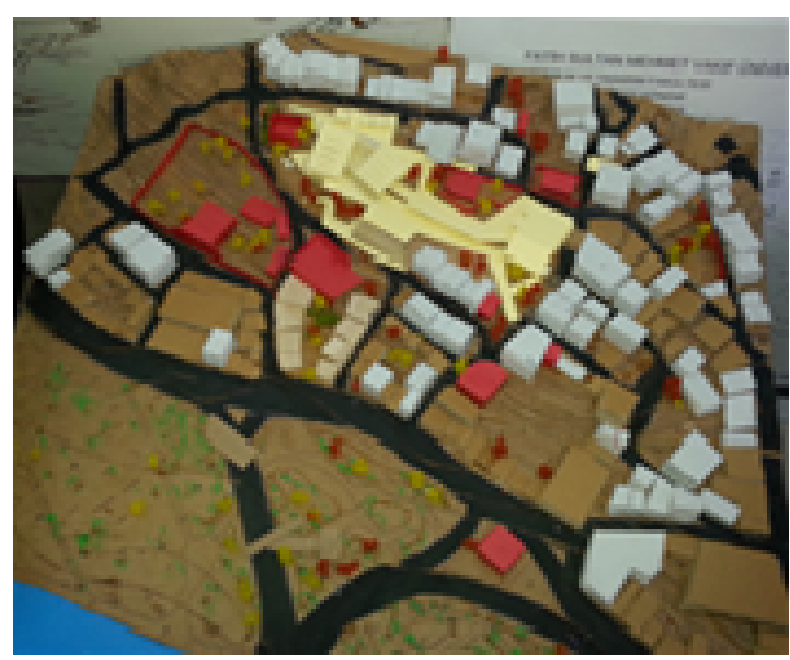

Fig. 45 A local district on global display, Hasköy.

Source: the author.

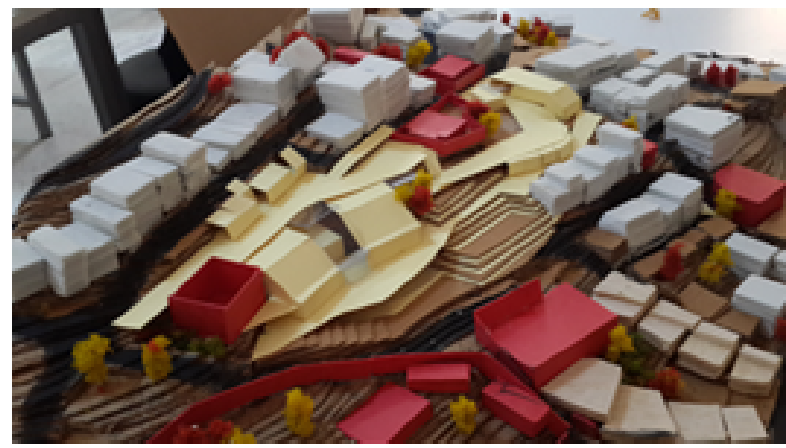

Fig. 46 A local district on global display.

Source: the author.

\section{Conclusions}

The present study aims to highlight the multidimensional content of urbanity, to encourage its discussion in architectural design education, and to emphasize the positive contribution of theoretical 
readings and phenomenological studies to urban design studios. Urban design studios, in which students examine social life, are environments that offer architectural students opportunities to develop their professional knowledge and for their individual maturation. While researching user profiles, social habits, everyday actions and rhythms of life, and the natural (such as natural wealth and topography) and built characteristics of the physical environment, within the context of similarities and differences between cultures and societies, the song of the space that designers hear is reflected from their mind and heart all the way into the details of the spaces being designed. Designers can achieve originality in their designs by interpreting, according to their individual sensibilities, the secrets of the values of the area that pertain to the global and the local. Interest and curiosity about regional life can be developed so as to encompass communities and cultures of other regions as well. Architects and architectural candidates who have an interest and curiosity about the diversity of life of societies on Earth feel that they are citizens of the world. As highlighted by Edmund O'Sullivan, the educational philosopher of the 21 st century, "the universe is a communion of subjects not a collection of objects". In this context, the present study also aims to emphasize the beneficial correlation of global and local dynamics as the two faces of urbanity; important more than ever for the big cities of the 21 st century if we advocate for a vivid and resilient city life and citizens.

\section{References}

[1] O’Sullivan, E. 2001. Transformative Learning, Educational Visions for the 21st Century. Toronto: University of Toronto Press.

[2] Sonne, W. 2014. Urbanität und Dichte im Städtebau des 20. Jahrhunderts. Berlin: DOM Publishers. (in German)

[3] Lampugnani,V. M., Frey, K., and Perotti, E. 2011. Stadt\&Text. Zur Ideengeschichte des Städtebaus im Spiegel Theoretischer Schriften seit dem 18. Jahrhundert. Berlin: Gebr.Mann Verlag. (in German)

[4] Lampugnani,V. M. 2011. Städte Einschreiben. Städte Entwerfen Anmerkungen zur Verwirklichung von Text und Projekt. Berlin: Gebr.Mann Verlag. (in German)

[5] Lampugnani,V. M. 2011. Die Stadt im 20. Jahrhundert. Visionen, Entwürfe, Gebautes. BandI-II. Berlin:Verlag Klaus Wagenbach. (in German)

[6] Mersmann, G. n.d. "Kommunen, Städte, Metropolen (Teil2)—Die Komplexität moderner Metropolen". Accessed October 10, 2014. http://de.paperblog.com/ kommunen-stadte-metropolen-teil2-die-kompleitat-moder ner-metropoln-863500. (in German)

[7] Hauser, S. 2011. Die Sinnlichkeit der Stadt. Über Grossstadtstraßen in Städtebautheorie und Literatur. Berlin: Gebr.Mann Verlag.

[8] Kuban, D. 2010. İstanbul Yazıları. İstanbul: Yem Yayın. (in Turkish) 